\title{
FENOMENA URBAN DAN BUDAYA MERANTAU SEBAGAI RANGSANG CIPTA DALAM KARYA SENI LUKIS
}

\author{
Imam Teguh Sugi Yetri ${ }^{1^{*}}$, Yuniarti Munaf ${ }^{2 *}$ Dharsono $^{3 *}$ \\ Minat Studi Seni Murni Program Pascasarjana \\ Institut Seni Indonesia Padang Panjang \\ Jl. Bahder Johan, Guguak Malintang, Padangpanjang, Kota Padangpanjang, 27126. \\ Sumatera Barat. Indonesia. \\ Email: imamteguhsugietri@gmail.com
}

\begin{abstract}
Abstrak
Urban merupakan permasalahan yang besar dan tidak berkesudahan sampai saat ini mulai dari permasalahan sosial, ekonomi, gaya hidup, kriminalitas dan lain sebagainya. Masalah ekonomi merupakan masalah yang sangat besar bagi kaum urban yang kurang pengalaman dan keterampilan untuk bertahan hidup di kota. Sumber inspirasi penciptaan karya lukis ini tidak terlepas dari fenomena yang terjadi di sekitar lingkungan masyarakat dan atas dasar pengalaman estetis. urban dalam penciptaan karya lukis ini adalah sebagai rangsang cipta atau objek penciptaan yang menginspirasi penciptaan. Kajian sumber dilakukan untuk meninjau beberapa karya yang menginspirasi dan mendahului karya-karya yang diciptakan, agar karya yang diciptakan memiliki nilai orisinalitas. Metode yang dilakukan yaitu dengan studi lapangan untuk mengumpulkan data dan fakta tentang objek penciptaan. Data dan fakta tersebut direnungkan kembali untuk menemukan perasaan terhadap objek penciptaan. Perasaan terhadap objek penciptaan merupakan tema atau subject matter penciptaan. Berdasarkan pengamatan serta perenungan yang dilakukan ditemukan perasaan prihatin. Perasaan tersebut diekspresikan melalui media seni lukis, menampilkan spontanitas garis dan warna yang memberikan pesona ekspresi dan emosional. Meskipun bentuk-bentuk yang menginspirasi bersumber dari realitas objektif, namun bentuk-bentuk tersebut diciptakan kembali untuk memperoleh bentuk-bentuk yang kuat sebagai perwakilan dari perasaan subjektif.
\end{abstract}

Kata Kunci: urban, seni lukis dan ekspresi

\begin{abstract}
Migration is the big comflik and not having an and untl, it is begin from some conflik like siciality, economy, life style, criminality, etc. The economy comflik is the big comflik from migrationer who have minimum experience and skill for survice in the city. Inspiration source of this paintings never irrespective of phenomenon happened in the circles society, and on basis aesthetic experience. Migration for this paintings as motivation to work or object inspiration composition. Examine of source to observe some inspiration works and precede it. in order it have or originality. Method to accumulate data and facta about object of composition. It is to muse again for find feeling of compisition object. It is theme or ( subject matter) composition. Based on the observation and mused be found apprehensive feeling. It is to expression by painting art media, line, and color spontanety forward to give express emotion enchantment. Although the inspiration forms have a resource from object real,however it is to make again for obtain the strong forms like representative subjective feeling.
\end{abstract}

Keywords: migration, painting, and expression

\section{PENDAHULUAN}

Urbanisasi diartikan sebagai proses pertambahan penduduk kota yang diakibatkan oleh peningkatan jumlah penduduk yang sangat cepat. Peningkatan ini disebabkan oleh pertumbuhan alami penduduk kota dan adanya perpindahan penduduk dari desa ke kota. Dari pengertian ini sering diartikan bahwa urbanisasi adalah perpindahan penduduk dari desa ke kota. Urbanisasi merupakan suatu budaya bagi masyarakat yang ada di desa untuk hidup di kota. Kota bagi mereka merupakan tempat yang menjanjikan baik dari segi perekonomian maupun gaya hidup.

Definisi urbanisasi berarti persentase penduduk yang tinggal di daerah perkotaan. Perpindahan manusia dari desa ke kota hanya salah satu penyebab urbanisasi. Perpindahan itu sendiri dikategorikan dua macam, yakni migrasi penduduk dan mobilitas penduduk. Migrasi penduduk adalah perpindahan penduduk dari desa ke kota yang bertujuan untuk tinggal menetap di 


\section{Gorga Jurnal Seni Rupa \\ Volume 07 Nomor 02 \\ p-ISSN: 2301-5942 | e-ISSN: 2580-2380}

kota, sedangkan mobilitas penduduk berarti perpindahan penduduk yang hanya bersifat sementara saja atau tidak menetap.

Terjadinya urbanisasi disebabkan beberapa faktor pendorong (Push Factors) diantaranya adalah: keadaan desa yang umumnya mempunyai kehidupan yang statis. Hal ini bisa terjadi karena adat istiadat yang masih kuat ataupun pengaruh agama, keadaan kemiskinan desa yang seakan-akan abadi. Lapangan kerja yang hampir tidak ada. Sebagian besar penduduknya hanya bergantung dari hasil pertanian, fasilitas pendidikan sekolah ataupun perguruan tinggi yang kurang memadai dan berkualitas, yang pada dasarnya faktor pendorong adalah faktor ekonomi.

Urbanisasi menimbulkan dampak positif dan dampak negatif. Dampak positif urbanisasi dapat berperan penting dalam perkembangan dan kemajuan ekonomi kota. Sedangkan yang jadi permasalahan besar adalah dampak negatif dari urbanisasi. Arus urbanisasi yang tidak terkendali dianggap merusak strategi rencana pembangunan kota, karena semakin minimnya lahan kosong di daerah perkotaan disebabkan banyak pemukiman-pemukiman liar. Dampak negatif yang bersifat sosial dan ekonomi, masyarakat desa yang umumnya kurang keterampilan untuk hidup di kota, dimana sebelumnya mereka hanya memiliki keterampilan dalam bertani dan beternak. Oleh karena itu sulit bagi mereka untuk memperoleh pekerjaan yang layak di kota. Mereka terpaksa bekerja sebagai buruh harian, pembantu rumah tangga, tukang becak, pedagang kaki lima, pemulung, pengamen, pengemis, dan lain sebagainya.

Sekian banyak permasalahan urbanisasi pengkarya sangat tertarik pada masalah ekonomi. Yaitu antara orang kaya dan orang miskin, orang kaya adalah orang yang mempunyai harta kekayaan yang lebih dari cukup, melimpah ruah, dan mereka juga dapat memenuhi kebutuhan-kebutuhan mewah seperti perumahan mewah, kendaraan mewah, pakaian, perhiasan mahal, dan lain sebagainya. Orang kaya di sini dapat dinilai dari segi ekonomi dan kekayaan harta benda saja. Orang miskin di sini adalah orang yang kekurangan dalam segi ekonomi, pendapatan mereka hanya dapat untuk memenuhi kebutuhan pokok saja seperti makanan, pakaian seadanya. Orang miskin di daerah urban sangatlah menyedihkan sekali, banyak diantara mereka yang tidak mampu memenuhi kebutuhan pokok. Kesenjangan kehidupan antara si kaya dan si miskin sangat kontras. Pengamen, pemulung, dan pengemis merupakan tontonan yang tak asing lagi bagi kita sehingga menimbulkan perasaan prihatin yang sangat mendalam.

Berdasarkan uraian di atas, persoalan ini menjadi penting dan layak untuk diangkat sebagai rangsang cipta dalam karya seni lukis, perasaan prihatin tentang urban tersebut diekspresikan melalui karya seni lukis, dalam karya ini akan hadir visualisasi bentuk orangorang urban, dengan bentuk abstrak, sehingga akan memudahkan pengkarya dalam menyampaikan isi hati, dan keprihatinan akan permasalahan urban.

\section{KAJIAN TEORI}

Kajian sumber yang dilakukan menyangkut tema, bentuk karya, material, aspek ekonomis dan ketersediaan medium seni lukis tersebut. Kajian sumber yang dilakukan adalah:

\section{Sumber Teori}

\section{1).Teori Seni Lukis}

Seni lukis dapat dikatakan sebagai suatu ungkapan pengalaman estetik seseorang yang dituangkan dalam bidang dua dimensi (dwimatra), dengan menggunakan unsur rupa, yaitu garis, warna, tekstur, shape, dan sebagainya. Medium rupa dapat dijangkau melalui berbagai macam jenis material seperti tinta, cat / pigmen, semen dan berbagai aplikasi yang memberi kemungkinan untuk mewujudkan karya seni rupa. (Dharsono, 2004: 36).

Lahirnya sebuah karya seni lukis tidak terlepas dari pengalaman pribadi seorang seniman baik pengalaman yang bersifat indah maupun tidak, keadaan tersebut yang mendasari lahirnya sebuah karya.

Seni lukis adalah hasil seni visual yang merupakan interpretasi seorang pelukis dalam menanggapi objekobjek dan hal yang ada di sekitarnya, dan kemudian ia ekspresikan lewat bentuk-bentuk seperti tanda, dan simbol. Menurut Paul Klee dalam Soedarso Sp. Mengatakan Seni tidak memproduksi apa yang kasat mata melainkan membuat ( yang tidak tampak ) menjadi dapat dilihat" seni adalah interpretasi, dan seni adalah simbol. (Soedarso, 2000: 85)

Seniman bebas dalam berekspresi, baik dalam penyampaian melalui bentuk-bentuk maupun simbol. Berdasarkan teori seni lukis di atas pengkarya dapat mengawali dasar pemikiran dalam berkarya seni, sehingga tidak ada keraguan dalam menciptakan karya seni lukis. 


\section{Gorga Jurnal Seni Rupa \\ Volume 07 Nomor 02 \\ p-ISSN: 2301-5942 | e-ISSN: 2580-2380}

\section{2).Teori Ekspresionisme}

Ekspresionisme adalah suatu aliran / yang berusaha untuk melukiskan aktualitas yang sudah didistorsikan ke arah suasana kesedihan, kekerasan ataupun tekanan batin yang berat. (Soedarso sp.2000: 99).

Ekspresionisme suatu paham dalam seni lukis di mana bentuk dan warnanya diubah sedemikian rupa, sehingga akan menunjang kesan-kesan dalam suasana seperti itu.

Ekspresionisme, berasal dari kata expresionism gabungan dari ek berarti "ke luar" atau kepanjangan dari mengekspresikan dan kata press berarti "tekanan", dan isme berarti "aliran". Merupakan sebuah aliran yang berusaha melukiskan aktulitas yang tidak sempurna ke arah suasana kesedihan, kekerasan atau tekanan batin yang berat. (Mike Susanto,116:2011).

Uraian di atas dapat disimpulkan bahwa, seni lukis sebagai sarana ungkapan pengalaman estetis yang merupakan bentuk ekspresi yang di dalamnya memiliki suatu makna tersendiri sebagai hasil pengolahan suasana bathin dengan pertimbangan unsur seni rupa.

\section{3).Simbol}

Simbol dapat diartikan sesuatu seperti tanda yang menyatakan sesuatu hal atau mengandung maksud tertentu. (Depdikbud, 1976: 556). Simbol dapat digunakan untuk keperluan apa saja. Misalnya dalam berkesenian maupun dalam realitas kehidupan masyarakat sehari-hari simbol sangat sering digunakan.

Simbol estetik adalah satu dan utuh karena tidak menyampaikan makna untuk dimengerti atau tidak dimengerti, melainkan pesan untuk diresapi. Pada karya selalu tersembunyi subjektivitas seniman atau perancangnya sebagai faktor penentu, karena karya estetik bukanlah deskripsi dari fakta objektif atau analisis ilmu pengetahuan. (Agus Sachari, 2002: 19).

Seperti yang diungkapkan oleh Susanne K. Langer dalam Agus Sachari berpendapat bahwa: "Realitas yang diangkat ke dalam simbol seni pada hakikatnya bukan realitas objektif, melainkan realitas subjektif, sehingga bentuk atau forma simbolis yang dihasilkan mempunyai ciri yang amat khas. Pengalaman subjektif bisa menjadi isu suatu forma simbolis yang ingin diungkapkan. Jika pengalaman ini adalah suatu perasaan yang kuat, maka pembentukan forma ini akan menunjukan ekspresivitas yang sedemikian kuat mengakar, sehingga bentuk forma tersebut seolah-olah hidup. Bentuk atau forma tersebut akan menjadi nilainilai estetik dari suatu objek." (Agus Sachari, 2002: 19-20).

\section{METODE PENCIPTAAN \\ 1.Eksplorasi}

Eksplorasi atau pencarian data dan informasi dilakukan pencarian dari berbagai sumber media elektonik dan media cetak. Pada tahapan ekspolorasi ini, pengkarya mencari dan mengumpulkan data tentang urban, baik berupa tulisan maupun gambar yang bersumber dari koran, televisi dan data dari hasil cerita juga wawancara dengan keluarga dan kerabat dekat. Data yang pengkarya cari tentang urban berupa data atau informasi mengenai dampak negatif pada urban yaitu persoalan gaya hidup, tatanan kota, ekonomi, kriminalitas dan gejala sosial. Setelah pengkarya mendapatkan data dan informasi tentang dampak negatif urban, pengkarya menetapkan satu persoalan yaitu mengenai masalah ekonomi. Bagi pengkarya masalah ekonomi ini sangat menarik untuk diangkat kemudian pengkarya mulai mengfokuskan pencarian data dan informasi mengenai masalah ekonomi dengan mencari data dengan studi pustaka dan menonton televisi sesuai dengan data yang pengkarya perlukan.

Setelah data dan informasi terkumpul pengkarya melakukan perenungan akan fenomena-fenomena sesuai data yang telah didapatkan tentang objek ditambah dengan cerita yang didapat dari keluarga pengkarya yang melakukan urban ke kota Jakarta. Di mana dari cerita dan pengalaman hidupnya di kota urban, permasalahan terbesar menurut dia adalah masalah perekonomian. Dari perenungan tersebut didapat perasaan yang akan diekspresikan atau sebagai subjek matter.

\section{Elaborasi}

Menganalisis dengan teliti dan rinci tentang data-data yang sudah didapat dari proses eksplorasi. Mengelaborasi data-data tersebut, dan membuat orisinalitas dengan tujuan membandingkan karya seni lukis yang akan dibuat dengan karya seni lukis yang serupa sebelumnya, konsep-konsep tersebut diubah sesuai dengan keinginanan pengkarya dan baru konsep pengkarya ditetapkan sebagai gagasan pokok dalam penggarapan karya.

\section{Sintesis}

Menyatukan semua hasil gagasan pokok yang telah dielaborasi untuk diwujudkan dalam bentuk konsepsi karya. Dengan membuat sketsa-sketsa bertema sama 


\section{Gorga Jurnal Seni Rupa \\ Volume 07 Nomor 02 \\ p-ISSN: 2301-5942 | e-ISSN: 2580-2380}

namun dalam visualisasi yang berbeda-beda. Sketsa alternatif merupakan penuangan ide kreatif yang dihasilkan dari proses analisis bentuk, teknik, media dan konsep penciptaan karya seni yang kemudian divisualisasikan dalam bentuk karya seni.

\section{Perwujudan}

Pembuatan karya di mulai dengan menyiapkan alat dan bahan. Tahap pertama dilakukan dengan pembuatan latar belakang, kemudian dilakukan pemberian tekstur pada bagian figur karya. Kemudian merespon tekstur dan latar belakang sehingga antara latar belakang dan figur nampak ada ruang. Proses selanjutnya memberi penekannan warna pada karya yang bertujuan sebagai pusat perhatian pada karya. Sketsa alternatif yang pengkarya ajukan di awal bertujuan sebagai jangkar agar karya sesuai dengan tema, tanpa harus menentukan sketsa terpilih. Hal ini bertujuan untuk kebebasan berekspresi dalam menciptakan karya.

\section{Penyelesaian/ Finishing}

Pada proses penyelesaian akhir/finishing, yaitu dengan memperbaiki bagian-bagian karya yang masih kurang tergarap agar lebih sempurna. Kemudian karya dilapisi dengan vernis untuk menjaga ketahanan cat pada kanvas, hingga karya benar-benar telah siap untuk disajikan/dipamerkan.

Salah satu contoh karya yang diciptakan adalah seperti gambar dibawah ini:

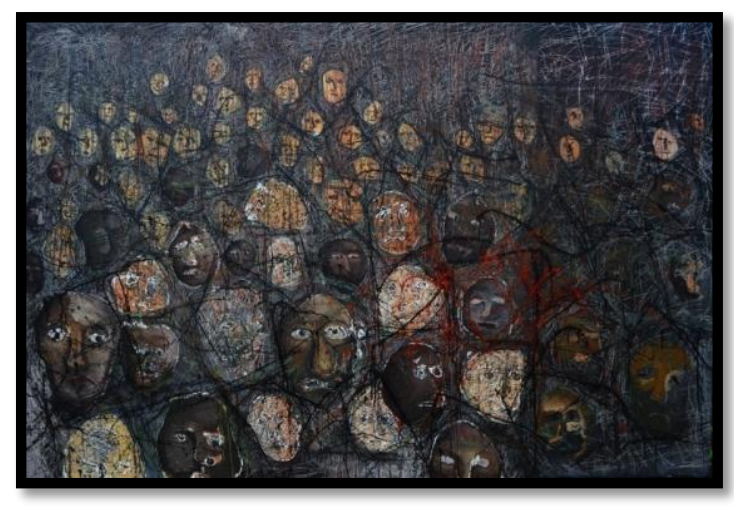

Gambar 1.

Judul: "Pamer Penderitaan"

Medium: Cat akrilik, media campur pada kanvas

Ukuran dan tahun: $130 \mathrm{~cm}$ x $195 \mathrm{~cm}, 2015$

( Dokumentasi Pribadi Imam Teguh S Y, 2018)

\section{Deskripsi Karya}

Karya yang berjudu "Pamer Penderitaan" berukuran $130 \mathrm{~cm}$ x $195 \mathrm{~cm}$ dibuat dengan cat akrilik pada kanvas dibuat pada tahun 2015, secara visual terlihat banyak potret wajah manusia dengan berbeda ukuran dan warna, pada beberapa potret terdapat kontur putih. Di antara potret terlihat cipratan cat dengan warna hitam, merah, abu-abu dan hijau. Pada latar belakang terlihat warna abu-abu dan garis putih yang bersilang, karya terlihat percikan cat warna merah dan juga sebagai pusat perhatian.

\section{Analisis dan Interpretasi}

Secara keseluruhan pada karya terlihat banyak figur wajah manusia dengan berbagai ukuran bertujuan memberikan kesan ruang pada karya. Pada latar belakang terlihat garis zig zag bertujuan untuk mengepresikan kesakitan. Warna dan garis-garis yang tidak sama secara intensitas warna, membangun komposisi dan ruang menjadi lebih estetik. Warna merah pada bagian depan karya bertujuan untuk menghadirkan intensitas warna yang berbeda sehingga menjadi pusat perhatian pada karya.

Karya yang dominan berwarna gelap dan terlihat banyak figur wajah manusia merupakan bentuk dari kegelisahan pengkarya. Cipratan cat berwarna merah merupakan simbol luka yang mendalam yang pengkarya rasakan.

\section{Objek Penciptaan}

Objek penciptaan dalam karya seni lukis ini adalah urbanisasi, urbanisasi adalah perpindahan masyarakat desa ke kota, orang-orang urban merupakan pelaku dari urbanisasi dalam budaya urban terdapat kesenjangan hidup antara si kaya dan si miskin, keprihatinan pengkarya terhadap kehidupan si miskin dalam urbanisasi inilah yang menjadi rangsang cipta dalam berkarya seni lukis.

\section{1).Subject Matter atau Tema Penciptaan}

Lahirnya sebuah tema dalam karya seni lukis ini tidak terlepas dari ketika pengkarya mengamati urbanisasi yang masih ada sampai saat ini banyak yang mengalami kegagalan sehingga hidupnya melarat di kota besar sehingga menimbulkan rasa prihatin terhadap pengkarya. Rasa prihatin tersebutlah yang akan pengkarya ekspresikan melalui simbol dan figurfigur manusia sehingga dengan tema tersebut dapat menyenangkan pengkarya ketika dalam proses berkarya seni lukis.

\section{2).Media}

Media yang digunakan dalam karya ini menggunakan media dua dimensi yaitu seni lukis, dengan media seni lukis inilah pengkarya memvisualkan subject matter urbanisasi ke dalam bentuk karya seni lukis. Pemilihan media dua dimensi sebagai landasan untuk berkarya disebabkan pengkarya sering melakukan eksplorasi dengan media dua dimensi, sehingga tidak menyulitkan pengkaraya untuk mevisualkan bentuk 


\section{Gorga Jurnal Seni Rupa \\ Volume 07 Nomor 02 \\ p-ISSN: 2301-5942 | e-ISSN: 2580-2380}

yang ingin pengkarya tuangkan ke dalam media dua dimensi.

\section{3).Bahasa Ungkap}

Bahasa ungkap yang pengkarya gunakan dalam karya seni lukis ini yaitu bersifat representasional. Semua karya seni memiliki from atau bentuk diantaranya ialah representasional, simbolik atau abstrak. Bentuk bisa dibuat dengan satu intensitas dan perencanaan untuk merepresentasi suatu bentuk objek secara apa adanya, yang dihasilkan adalah bentuk yang mengimitasi objek yang dipilih. Bisa pula objek itu berupa hasil penyerderhanaan dari objek yang direpresentasikan, misalnya hanya mengutamakan bagian-bagian khusus yang dipandang mewakili karakter khusus dari objek yang mau digambarkan. Bentuk bisa merupakan suatu abstraksi dari sesuatu, dan produk akhirnya berupa bentuk yang abstrak. (Donis A. Dondis 1986, dalam, M Dwi Marianto. Menempa Quanta Mengurai Seni. 29: 2011)

Setiap karya seni memiliki bentuk, bisa berupa bentuk representasional, simbolik atau bentuk abstrak. Dalam penyampain bentuk karya seni seorang seniman menyampaikan materi subject (subject matter) medium yang dipilih. Dengan demikian memahami sebuah karya seni harus dilihat, dari sudut pandang bentuk karya itu sendiri, apakah dia bentuk representasional, simbolik atau abstrak.

\section{4).Medium}

Pesona ekspresi dan emosional. Kecenderungan ini merupakan pendekatan medium yang digunakan dalam karya lukis ini menggunakan medium campuran seperti: pasir, serbuk kayu, untuk tekstur dan cat akrilik di atas kanvas. Ketertarikan menggunakan medium disebabkan medium ini pengkarya telah sering melakukan eksplorasi sehingga telah terkuasai oleh pengkarya dalam berkarya seni lukis. Medium yang digunakan ini tidak mempersulit pengkarya untuk mencapai karakter bentuk yang diinginkan, sehingga lahir kepuasan tersendiri ketika karya itu telah selesai.

Garapan pada karya ini menampilkan gaya spontanitas garis dan warna yang memberikan gaya ekspresionis, yaitu suatu gaya seni yang berusaha untuk menggambarkan perasaan subjektif. Seperti yang diungkapkan oleh Paul Cezanne dalam Dharsono Sony Kartika berpendapat bahwa :

"Pelukis berpikir menggunakan warna. Tugas pelukis adalah memproduksi hal yang berdimensi tiga ke dalam suatu bidang datar (kanvas). Ruang dan isi tidak bisa dipisahkan. (Dharsono, 2004:74).

Pendapat tersebut menyatakan bahwa ketika seorang pelukis melukis alam, tidak ingin sekedar meniru alam (mimesis), melainkan alam ingin diciptakan kembali untuk memperoleh bentuk-bentuk yang kuat.

\section{KESIMPULAN DAN SARAN}

Penciptaan seni lukis terus mengalami kemajuan dan perkembangan seiring dengan spirit dan jiwa zaman. Berbagai ide kreatif muncul dalam berbagai media dan medium seni lukis dengan tetap mempertahankan karakter seni lukis dan mempertimbangkan nilai estetik serta kandungan maknanya.

Penciptaan karya seni lukis ini sangatlah memuaskan baik dalam segi teknik, konsep dan secara visual bagi pengkarya. Secara teknik pada awal proses berkarya. Pengkarya merasa kesulitan hal itu disebabkan pengkarya terlalu banyak menggunakan teknik, sehingga pengkarya kesulitan dalam memilih teknik yang merasa cocok dengan konsep yang diangkat. Dengan adanya proses bimbingan baik dari pembimbing, maupun beberapa saran dari senior pasca sarjana, pengkarya mulai mendapatkan titik terang tentang teknik mana yang lebih tepat.

Pengamatan objek tentang urban merupakan kajian yang menarik untuk diamati lebih lanjut dan secara mendalam. Pengkarya mengamati dari sisi atau dampak negatif dari urban yaitu mengenai ekonomi yang diekspresikan melalui karya seni lukis. Pengkarya menyarankan untuk pengamatan objek lebih lanjut dan mendalam kepada pencipta seni dan pengkaji seni dari teman-teman seni kriya, DKV, maupun pertunjukan seni baik dari dampak negatif urban yang lain seperti sosial, kriminalitas, gaya hidup dan lain sebagainya dan juga dari dampak positif urban. Sehingga dapat memberikan wacana baru dalam seni khususnya di Institut Seni Indonesia Padangpanjang.

Penciptaan karya seni lukis ini pengkarya menggunakan medium cat akrilik di atas kanvas. Melalui karya ini Pengkarya berharap dapat menjadi acuan dan pedoman penciptaan karya seni lukis untuk ke depannya.

\section{DAFTAR RUJUKAN}

Depdikbud. 1990. Kamus Besar Bahasa Indonesia. Jakarta: Balai Pustaka.

Djelantik, A.A.M. 1999. Estetika Sebuah Pengantar. Bandung: MSPI. 
Kartika, Dharsono Sony. 2004. Seni Rupa Modern.

Bandung: Rekayasa Sain.

Marianto, M Dwi. 2011, Menempa Quanta

Mengurai Seni. Yogyakarta: Bahan

Penerbit ISI Yogyakarta.

Sachari, Agus. 2000. Estetika, Makna, Simbol dan Daya. Bandung ITB.

Sp.Soedarso. 2000, Sejarah Perkembangan Seni

Rupa Modren. Jakarta: Studio Delapan

Puluh.

Suparli. 1983, Tinjauan Seni. Departemen

Pendidikan dan Kebudayaan.

Susanto, Mikke. 2011, Diksi Rupa. Yogyakarta:

Dictiart Lab dan Djagad Art Hous. 